\title{
ENGINE TESTING OF RME ADDITIVES
}

\author{
Andrzej Żóltowski, Paulina Luiza Grzelak \\ Motor Transport Institute \\ Environment Protection Centre \\ Jagiellonska Street 80, 03-301 Warsaw, Poland \\ tel.: +48224385518, +48224385530 fax: +48224385401 \\ e-mail:andrzej.zoltowski@its.waw.pl,paulina.grzelak@its.waw.pl
}

\begin{abstract}
Reducing the emission of pollutants emitted from motor vehicles, and now also in greenhouse gas emissions, is a result of European Union policy. Vehicle design changes are just one way of reducing emissions of harmful substances and greenhouse gases. The second way is to change the type of fuel, by which the vehicle's engine is powered, that is the substitution of conventional fossil fuels derived from crude oil, such as gasoline or diesel fuel by so-called renewable fuels, for which the $\mathrm{CO}_{2}$ emissions are measured not only in the engine exhaust system, but also by analysis "from the source to the wheel" WTW (Well-to-wheel) - is much smaller. As part of this task the Directive 2009/28/EC introduced for all Member States to the use of renewable energy, biofuels, alternative fuels to a certain extent share of the energy and conventional fuel by 2020.

This paper presents the results of measurements of emissions on the dynamometer with a diesel engine powered by six kinds of mixtures of diesel oil and rapeseed oil methyl ester (RME) - with esters containing 0 (clean diesel), 20, 40, 60, 80 and 100 (pure rapeseed oil methyl esters)\% in the fuel. We analysed the reasons for the impact of changes in fuel composition on selected limited exhaust components. We found, that the addition of esters of rapeseed oil to the diesel fuel can be a reason of reducing the emissions of $\mathrm{CO}, \mathrm{CO}_{2}$, and $\mathrm{THC}$ in the exhaust gases of tested engine and increased emissions of $N O_{x}$ and $P M$.
\end{abstract}

Keywords: renewable fuels, specific emissions of pollutants

\section{Introduction}

European Union policy in the field of reducing the mass emissions of pollutants from motor vehicles for decades concerns the limited exhaust gas components like CO, THC, NMHC, NOx, PM and PN recently. However, for last several years the attention of ecologists is focused on greenhouse gases emissions. In the automotive industry branch the reducing greenhouse gas emissions, including mainly $\mathrm{CO}_{2}$ emissions, goes multifaceted and at many levels. The first step in this area was obligation to measure in type approval tests $\mathrm{CO}_{2}$ emissions in passenger and light duty vehicles. After many years of waiting, along with the introduction of Euro VI limit, this obligation was extended to the measurement of the $\mathrm{CO}_{2}$ specific emission in approval tests of heavy duty engines. Following the implementation of the $\mathrm{CO}_{2}$ emissions measurement, come the first forms of impose to the vehicle manufacturers, charges for the environment in case of producing vehicles having too high $\mathrm{CO}_{2}$ emissions.

Limits of the greenhouse gas emissions from motor vehicles as a effect of appropriate structural modifications of vehicles and their engines are just one of the ways of restricting the emissions. Parallel to this one, the EU legislation requires the use of renewable fuels instead the fossil fuels. For renewable fuels the total $\mathrm{CO}_{2}$ emissions measured not only in engine exhaust system, but on the way from the source to the wheel (well to wheel) is much smaller. The implementation of this approach is Directive 2009/28/EC, which introduced for each EU Member State the obligation to apply till the year 2020 a certain share of renewable fuels and energy on the inner markets. For Poland the target is $15 \%$.

In Tab. 1 is shown the possible effect of a $\mathrm{CO}_{2}$ emission reductions as a result of some alternative fuels using. One among the fuels listed in this table is biodiesel produced from rape oil seed which is essentially the rapeseed oil methyl ester (RME). 
In this paper will be discussed some aspects of test bench engine testing fuelled with mixtures of diesel oil and rapeseed oil methyl esters.

Tab. 1. Reducing $\mathrm{CO}_{2}$ emissions for produced biofuels (without net $\mathrm{CO}_{2}$ emissions due to land use change) [1]

\begin{tabular}{|l|c|c|}
\hline \multicolumn{1}{|c|}{ Type of fuel } & $\begin{array}{c}\text { Typical limits } \\
\text { for greenhouse } \\
\text { gas emissions }\end{array}$ & $\begin{array}{c}\text { Standard limits for } \\
\text { greenhouse gas } \\
\text { emissions }\end{array}$ \\
\hline ethanol from sugar beet & $61 \%$ & $52 \%$ \\
\hline ethanol from wheat (process fuel - not specified) & $32 \%$ & $16 \%$ \\
\hline ethanol from wheat (lignite as process fuel in CHP plant) & $32 \%$ & $16 \%$ \\
\hline $\begin{array}{l}\text { ethanol from wheat (natural gas as process fuel in conventional } \\
\text { boiler) }\end{array}$ & $45 \%$ & $34 \%$ \\
\hline ethanol from wheat (natural gas as process fuel in CHP plant) & $53 \%$ & $47 \%$ \\
\hline ethanol from wheat (straw as process fuel in CHP plant) & $69 \%$ & $69 \%$ \\
\hline $\begin{array}{l}\text { corn ethanol produced in the Community (natural gas as process fuel } \\
\text { in CHP plant) }\end{array}$ & $56 \%$ & $49 \%$ \\
\hline ethanol from sugar cane & $71 \%$ & $71 \%$ \\
\hline biodiesel from rapeseed & $45 \%$ & $38 \%$ \\
\hline biodiesel from sunflower & $58 \%$ & $51 \%$ \\
\hline biodiesel from soy bean & $40 \%$ & $31 \%$ \\
\hline biodiesel from palm oil (technology not specified) & $36 \%$ & $19 \%$ \\
\hline biodiesel from palm oil (technology with methane capture) & $62 \%$ & $56 \%$ \\
\hline biodiesel from waste vegetable or animal oil & $88 \%$ & $83 \%$ \\
\hline hydrotreated vegetable oil from rapeseed & $51 \%$ & $47 \%$ \\
\hline hydrotreated vegetable oil from sunflower & $65 \%$ & $62 \%$ \\
\hline hydrotreated vegetable oil from palm oil (technology not specified) & $40 \%$ & $26 \%$ \\
\hline $\begin{array}{l}\text { hydrotreated vegetable oil from palm oil (technology with methane } \\
\text { capture) }\end{array}$ & $68 \%$ & $65 \%$ \\
\hline pure vegetable oil from rapeseed & $58 \%$ & $57 \%$ \\
\hline $\begin{array}{l}\text { biogas from organic municipal waste as compressed natural gas } \\
\text { (biomethane) }\end{array}$ & $80 \%$ & $73 \%$ \\
\hline biogas from wet manure as compressed natural gas (biomethane) & $84 \%$ & $81 \%$ \\
\hline biogas from dry manure as compressed natural gas (biomethane) & $86 \%$ & $82 \%$ \\
\hline
\end{tabular}

\section{Test fuels}

In the tests were used mixtures of diesel oil and rapeseed oil methyl ester, whose physicchemical properties are shown in Tab. 2.

Tab. 2. Selected physic-chemical properties of diesel oil and rapeseed methyl esters used in vehicles tests

\begin{tabular}{|l|l|l|l|}
\hline Property & Unit & Diesel & RME \\
\hline FAME content & $\%(\mathrm{v} / \mathrm{v})$ & 4.5 & 99.1 \\
\hline Calorific value & $\mathrm{MJ} / \mathrm{kg}$ & 42.5 & 39.5 \\
\hline Cetane number & - & 52.8 & 52.5 \\
\hline Density at temp. $15^{\circ} \mathrm{C}$ & $\mathrm{kg} / \mathrm{m}^{3}$ & 830.1 & 882.7 \\
\hline Surface tension & $\mathrm{N} / \mathrm{m}$ & $22.5 \cdot 10^{3}$ & $25.4 \cdot 10^{3}$ \\
\hline Kinematic viscosity at temp. $40^{\circ} \mathrm{C}$ & $\mathrm{mm} / \mathrm{s}$ & 2.693 & 4.463 \\
\hline Cold filter plugging point (CFPP) & ${ }^{\circ} \mathrm{C}$ & -31 & -25 \\
\hline Chemical analysis & & & \\
- content of C (measured) & $\%$ & 87.95 & 79.01 \\
- content of H (measured) & $\%$ & 11.94 & 12.85 \\
- content of O (calculated from the balance) & $\%$ & 0.11 & 8.14 \\
\hline H/C & - & 1.83 & 1.93 \\
\hline O/C & & 0 & 0.08 \\
\hline
\end{tabular}


Comparing these two test fuels the attention should be paid to the difference in their chemical composition, particularly in terms of oxygen. The content of this component in esters is about $8 \%$, while in diesel oil it is close to zero. RME heat value expressed in $\mathrm{MJ} / \mathrm{kg}$ is smaller by app. $7 \%$ in comparison to diesel oil, but expressed in $\mathrm{MJ} / \mathrm{dm}^{3}$ only by about $1 \%$ due to the greater density of the esters. The greater contribution of the hydrogen mass fraction in ester molecules suggests the possibility of reducing the $\mathrm{CO}$ and $\mathrm{THC}$ emissions in products of combustion of this fuel.

\section{Tests results analysis}

The study included measurement in standard engine emission cycles on test bench equipped with a suitable measurement devices. Selected test cycles comes from different type approval regulations for vehicle engines (ESC, ETC and WHTC), off-road machineries (NRTC) and the American regulations (HDTC). The tested object was an A115DI engine type deriving from delivery truck. It met Euro III requirement.

In order to minimize the influence of random errors on the measurement results, there were made a series of emission tests, in which the tested engine was powered by six different blends of rapeseed oil methyl esters and diesel fuel containing $0 \%$ of esters (pure diesel fuel), 20, 40, 60, 80 and 100 (pure methyl esters of rapeseed oil) \% of the fuel. The test results are shown on Fig. 1 and 2. The diagrams are drawn as a function of the mass fraction of the rapeseed oil methyl ester in the fuel, expressed as a decimal fraction. The values of measured emission were approximated with linear regression lines, and obtaining curves showed the emission trends as a function of fuel composition (fraction of the ester).

Figures 1 and 2 give possibility clearly to identify the trends of pollutant emission changes that occur with an increase of the ester participation in the tested fuels. This trends are symbolically shown in Tab. 3, where the arrow pointing down indicates that the emission of exhaust component in selected test decreases with the increase of esters participation in the fuel, while the arrow pointing up means the opposite tendency.

Tab. 3. Trends in changes of emissions in selected tests as a result of esters addition in diesel fuel

\begin{tabular}{|c|c|c|c|c|c|}
\hline \multirow{2}{*}{ Test type } & \multicolumn{5}{|c|}{ engine A115DI } \\
\cline { 2 - 6 } & $\mathrm{CO}_{2}$ & $C O$ & $N O_{x}$ & $T H C$ & $P M$ \\
\hline$E S C$ & $\downarrow$ & $\downarrow$ & $\uparrow$ & $\downarrow$ & No change \\
\hline$E T C$ & $\downarrow$ & $\downarrow$ & $\uparrow$ & $\downarrow$ & $\uparrow$ \\
\hline$H D T$ & $\downarrow$ & $\downarrow$ & $\uparrow$ & $\downarrow$ & $\uparrow$ \\
\hline NRTC & $\downarrow$ & $\downarrow$ & $\uparrow$ & $\uparrow$ & $\uparrow$ \\
\hline WHTC & $\downarrow$ & $\downarrow$ & $\uparrow$ & $\downarrow$ & $\uparrow$ \\
\hline
\end{tabular}

Analysing the information collected in Tab. 3 it can be concluded, that the addition of the esters to the diesel fuel will cause in tested engine increase of $\mathrm{NO}_{\mathrm{x}}$ and $\mathrm{PM}$ emissions, and decrease the emissions of $\mathrm{CO}, \mathrm{CO}_{2}$, and THC in most of performed tests. The decline of $\mathrm{CO}, \mathrm{CO}_{2}$, and THC might be expected, taking into account the higher hydrogen content in the esters. The relatively smallest is the difference in $\mathrm{CO}_{2}$ emissions, because in average it is not greater than 1$2 \%$. However, this value is not the result of measurement error, because on the presented figures it is possible to see clearly the decreasing trend of $\mathrm{CO}_{2}$ emissions with an increase in participation of esters in the fuel. Taking into account that methyl esters of rapeseed oil are renewable fuels, the 
use of this fuel will decrease the global $\mathrm{CO}_{2}$ emissions, calculated by the WTW (well to wheel) method by approximately $40 \%$ (Tab. 1). Analysing the other exhaust gas components, we can see that in the ETC cycle (Fig. 2) the THC emissions decreased by $32 \%$ (compared to diesel fuel to pure rapeseed oil esters), while $\mathrm{NO}_{\mathrm{x}}$ emissions increased by $40 \%$ and $\mathrm{PM}$ increased by $44 \%$.
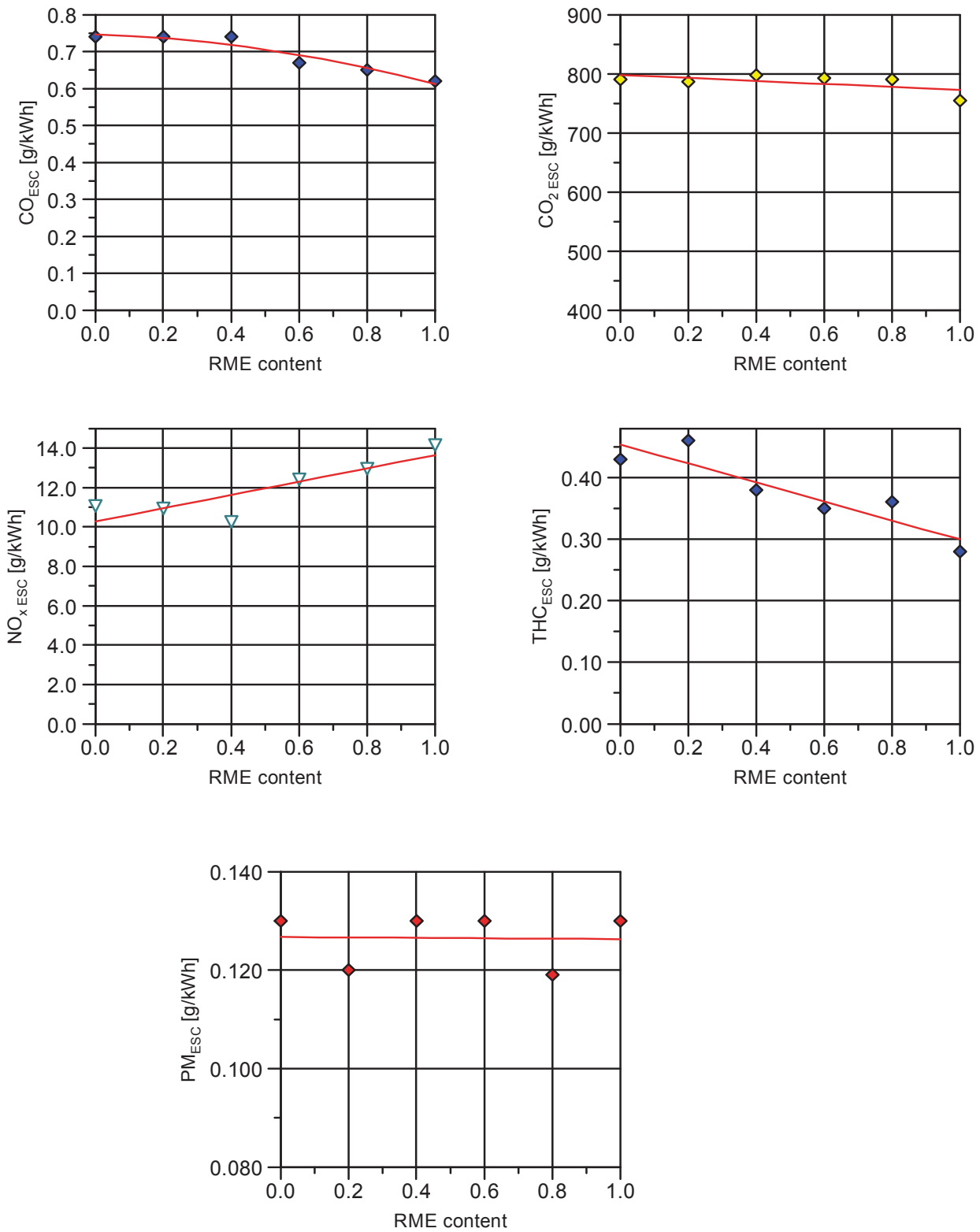

Fig. 1. Specific emission In European Steady Cycle (ESC) versus RME content in diesel oil

The major factors of the $\mathrm{NO}_{\mathrm{x}}$ formation are high combustion temperature, rich local oxygen concentration, and long residence in the high temperature atmosphere. Obviously, with RME, the temperature in combustion chamber could be increased and amount of oxygen is also increased, which could improve combustion and lead to the formation of higher $\mathrm{NO}_{\mathrm{x}}$ emissions.

It is well known that the diesel particle consists of soluble organic friction (SOF), dry soot and sulphate. Due to the fact that the RME contain less sulphur, compared to diesel fuel and smoke opacity of the tested engine fuelled with RME was lower than for diesel fuel, it can be expected that the particles emitted from the engine powered by biodiesel will contain less soot and sulphates. Therefore, the only explanation for the increase of particulate emissions mass would be an increase of soluble organic friction. In general, the origins of soluble organic friction in PM are partly of lubrication oil, unburned oil, and compounds created during fuel combustion. 

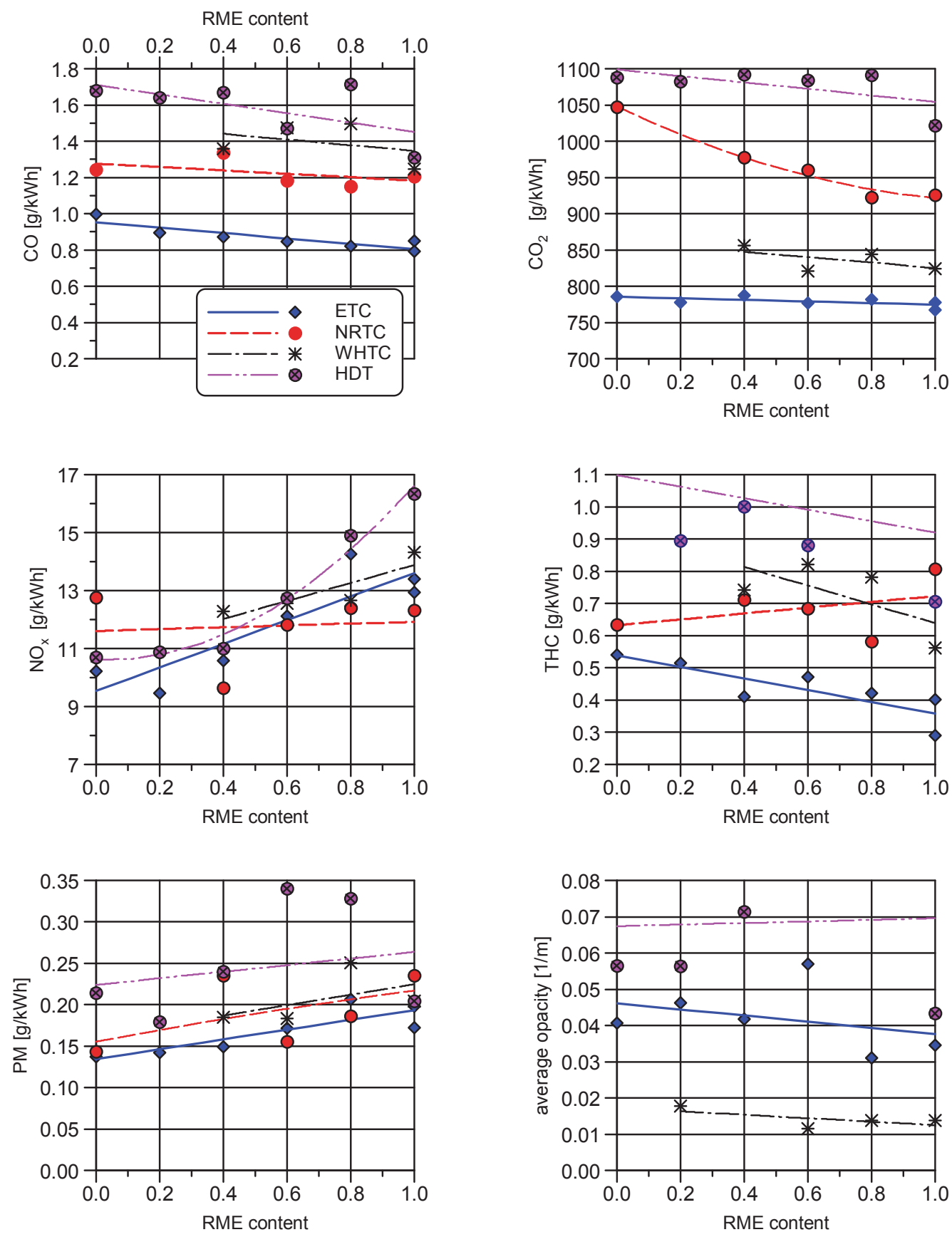

Fig. 2. Specific emissions in different transient cycles versus RME content in diesel oil

Some authors reported [5] that the higher SOF fraction observed with the biodiesel or biodiesel blends could be attributed to the low volatility of biodiesel, which was caused by the higher boiling point, higher viscosity and higher density, leading to the worse mixture of fuel and air in chamber and incomplete combustion. In the end, the unburned oil and compounds of uncompleted combustion increase with biodiesel content in fuel, and result in the increase of proportion of SOF in turn. The more the biodiesel is in the blended fuels, the lower the sulphur content will be. The most possible explanation of the observed phenomena increase of sulphate proportion is just a consequence of the sharper reductions in smoke and a slighter decrease in sulphate mass of biodiesel blends

In order to analyse the impact of fuel composition on the smoke emission, on the Fig. 2 there is provided diagrams showing the change of the average exhaust gas opacity as a function of the fuel constitution. This value is calculated as the arithmetic mean of the opacity values recorded during 
corresponding cycles. Analyse of these curves indicates, that the addition of RME to diesel fuel is beneficial for reducing opacity, given that the maximum decrease of the average exhaust opacity is equal from zero to app. $20 \%$, depending on the nature of the engine work (the type of used emission test).

The observed decrease in exhaust smoke cannot be explained by the quality of fuel atomization during the injection, because the viscosity and surface tension are greater for RME than for diesel fuel. These parameters are rather reason of worse startability at low temperatures of RME-fuelled engines [1].

In [3] is stated that the presence of the bonded oxygen could explain the decrease of smoke, which reduces the probability of soot nuclei formation in locally rich zones. When sufficient oxygen is available, soot precursors species react with oxygen or oxygen-containing radicals (like $\mathrm{OH}, \mathrm{O})$ and eventually produce $\mathrm{CO}$ rather than aromatics and soot. Moreover, the increase of oxygen content in blends means a decrease of carbon content, which is the major contributor of soot formation. Some researchers claim [4] that reductions of opacity can be due to the dilution of aromatics, which were considered as the soot precursors.

\section{Conclusions}

1. Compared with baseline diesel fuel, the biodiesel blends give higher $\mathrm{NO}_{\mathrm{x}}$ and $\mathrm{PM}$ emissions.

2. $\mathrm{RME}$ blends give lower $\mathrm{CO}, \mathrm{THC}, \mathrm{CO}_{2}$ emission compared to diesel fuel.

3. The smoke opacity of biodiesel blends decreases remarkably, in comparison with baseline diesel fuel.

4. The dry soot proportions decrease with increase in the proportion of biodiesel and the SOF and sulphate proportions increase with the percentage of biodiesel.

\section{References}

[1] Dyrektywa Parlamentu Europejskiego I Rady 2009/28/WE z dnia 23 kwietnia 2009 r. w sprawie promowania stosowania energii ze źródeł odnawialnych zmieniająca i w następstwie uchylająca dyrektywy 2001/77/WE oraz 2003/30/WE.

[2] Radzimirski, S., Żółtowski, A., Influence Of RME Component in Diesel Fuel On CI Engine Emission, Konferencja Euro Oil \& Fuel, Prace Naukowe Instytutu Nafty I Gazu, Nr 172, Kraków 2010.

[3] Lapuerta, M, Rodríguez-Fernández, J, Agudelo, J. R., Diesel particulate emissions from used cooking oil biodiesel, Bioresour Technol, 2008b, 99:731-40.

[4] Lei Zhu, Wugao Zhang, Wei Liu, Zhen Huang Experimental study on particulate and NOx emissions of a diesel engine fueled with ultra low sulfur diesel, RME-diesel blends and PME-diesel blends, School of Mechanical Engineering, Shanghai Jiaotong University, Shanghai, PR China.

[5] Lin, Y. C., Lee, W. J., Chao, H. R., Wang, S. L., Tsou, T. C., Chang-Chien, G. P., et al., Approach for energy saving and pollution reducing by fueling diesel engines with emulsified biosolution/ biodiesel/diesel blends, Environ Sci Technol, 42:3849-55, 2008. 